\title{
Are Euro Interest Rates led by FED Announcements?
}

\author{
Andrea Monticini ${ }^{a, *}$ \\ Giacomo Vaciago ${ }^{b}$ \\ ${ }^{a}$ University of Exeter, School of Business and Economics, Streatham Court, \\ Rennes Drive, EX4 4PU Exeter (UK) \\ ${ }^{b}$ Catholic University of Milan, Via Necchi 5, 20123 Milano, Italy
}

December 4, 2005

\begin{abstract}
This paper investigates, for the first time, the reactions of markets to the monetary policy decisions of their own Central Bank and to the decisions of the Central Banks of other countries. In particular, using daily interest rates to estimate the impact of the monetary policy announcements of a Central Bank, we analyse the effect of the FED, ECB, and BoE monetary policy announcements on their own markets, and on the others. Surprisingly, we find that while the US rates respond only to FED announcements, and the British rates respond mainly to BoE announcements and marginally to FED announcements, the response of Euro bond rates to the FED announcements is stronger than their response to ECB announcements.
\end{abstract}

JEL classification: E4, E43, E52, F42

Keywords: Monetary policy; Term structure of interest rates; Interdependence.

${ }^{*}$ Corresponding author.

E-mail address: A.Monticini@exeter.ac.uk 


\section{Introduction}

The main instrument of monetary policy is the setting of Central Bank rates, which can either follow a "reaction function" - Taylor rule - or be decided on a discretionary basis. In both cases it is very important how the Central Bank announces its policy.

In the 1990's numerous studies analysed the transmission mechanisms of monetary policy, focusing particularly on the reaction of market interest rates to the decisions and, more generally, to the monetary policy announcements of Central Banks.

In our opinion, knowing how markets respond to monetary policy announcements is of extreme importance for both financial operators and monetary authorities: operators want to know how monetary policy will affect their decisions, and the Central Bank wishes to know how its decision on interest rates is transmitted to the market and how much autonomy to determine rates it actually enjoys.

It is interesting, with the increased globalization of financial markets, to look also at how domestic interest rates are influenced by the monetary policy announcements of other central Banks.

The aim of this study is to examine how the announcements of a Central Bank are reflected on its domestic market and to what extent they are able to influence the financial markets of other countries. We analyse the effects of the FED's, the ECB's, and the BoE's monetary policy announcements on their own and other markets, using future rates to separate expected from unexpected policy decisions. In accordance with the efficient markets hypothesis, we show that the response of domestic interest rates to the surprise component of monetary policy is stronger than the expected component of policy action, but we also find that Euro interest rates respond significantly to FED announcements. This amounts to a temporary loss of monetary sovereignty for Europe's Central Banks.

More generally, this finding can be used to improve the effectiveness of 
monetary policy: it is in fact essential for a Central Bank to take account of the capacity of others to communicate and of the leadership effects this has, if it wishes to conserve its sovereignty over its own yield curves at all times.

This paper is organized as follows. The next section describes the channels through which monetary policy announcements by the Central Bank of one country can cause changes on the domestic market of another country. The third section is a review of earlier studies assessing market reactions to monetary policy actions. The fourth section describes the use of future

prices to obtain a measure of the expectations of monetary policy announcements. The fifth section describes the empirical model we estimate, while the following sections describe the results we obtain.

\section{Transmission channel}

What are the channels through which monetary policy announcements by the Central Bank of one country can cause changes on the domestic market of another country? Generally speaking there are three main channels. The first depends on the regime in which the monetary policy is set. Some Central Banks do in fact set themselves the target of stabilizing a relationship in which one of the two variables involved is controlled by a foreign central Bank. This occurs for example when monetary policy seeks to stabilize the exchange rate. In this case, monetary policy is determined by an exogenous variable controlled by a foreign Central Bank. When that foreign central Bank announces a change in its monetary policy, this change also is transmitted to the other monetary market.

The second channel is connected with the growing integration of financial markets and the relative spillover effects. An announcement by one Central Bank can in fact create arbitrage phenomena which tend to be eliminated by movements of capital. Since the transaction costs of transferring capital from one market to another are low in integrated financial markets, an 
announcement by a foreign Central Bank will generate capital flows which will have an impact on its domestic financial markets.

Finally, the third channel is connected with the publishing of macroeconomic data. A monetary policy announcement by a Central Bank may reveal important economic information concerning another country. Consider, for example, an economic outlook which contains explicit references to the economic conditions of other economies or in any case useful information for forecasting the economic performance of other countries.

\section{A review of earlier studies}

An early paper assessing market reactions to monetary policy actions is that of Cook and Hahn (1989), who examined the one-day response of bond rates to changes in the target Fed Funds rate from 1974 through 1979. Cook and Hahn begin by compiling a record of the changes in the Federal Reserve's target over this period. They examine both the records of the Federal Reserve Bank of New York (which implemented the changes) and the reports of the changes in The Wall Street Journal. As Cook and Hahn describe it, the actual Federal funds rate moves closely with the Federal Reserve's target. Moreover it is highly unlikely that the Federal Reserve was changing the target in response to factors that would have moved the funds rate even in the absence of the policy changes, i.e. it is unlikely that in the absence of the Federal Reserve's actions the Federal funds rate would have moved by discrete amounts. Their procedure was to regress the change in the bill, note, and bond rates on the change in the Fed's target funds rate for a sample consisting of 75 days during which the Fed had changed the funds rate target. They find that the response to the target rate increases is positive and significant at all maturities, but noticeably smaller at the long end of the yield curve. In addition, Cook and Hahn examine the relationship between changes in interest rates and future changes in the target, but they find little evidence that the target rate changes were anticipated. 
In contrast with this research, Roley and Sellon (1995), using Cook and Hahn's eventstudy approach to the 1987-1995 period, find a statistically insignificant response of bond rates to changes in the target funds rate. Later on, more sophisticated econometric procedures were used. Edelberg and Marshall (1996), using a VAR (Vector Autoregressive) model to study monetary policy, found a large response of bill rates to policy shocks, and a small response of bond rates.

In 2001, Kuttner used the Federal Funds rate futures to separate expected from unexpected changes in the Federal Funds target rate. Examining the impact of monetary policy on bill, note, and bond yields, the author showed that the response of interest rates to expected changes is insignificant, while the response to unexpected change is statistically significant and relevant to explain the impact of monetary policy changes. These results support the hypothesis of rational expectations of economic agents.

Perez-Quiros and J. Sicilia (2002) examined the predictability of the monetary policy of the ECB and analysed the impact of monetary policy decisions on the yield curve, using daily data. As regards predictability, their evidence suggested that markets have not been surprised by monetary policy decisions of the ECB, i.e. markets have been able to predict the Governing Council's decisions on key ECB interest rates fairly accurately. As regards transmission of the unexpected component of monetary policy decisions to the yield curve, they provide evidence that meetings smooth out the impact of the monetary policy shocks (daily changes in short-term interest rates) which have been generated outside meeting days.

Ross (2002) looking at the relations between monetary policy announcements and the market's reaction, makes a comparative analysis on the market's ability to understand the ECB's, FED's, and BoE's decisions. In this work it appears that the market is able to anticipate correctly the FED's and the BoE's decisions. With regard to the ECB, the market has difficulty to anticipate changes in the interest rate. The author thinks that this may be explained by the larger number of meetings, which are a source of 
confusion.

Various studies on money markets in the literature consider the importance of foreign announcements to domestic markets. Kim, Kortian and Sheen(2000) look at the Australian financial market. They find that American macroeconomic news affects Australian interest rates.

In another study Gravelle and Moessner (2001) demonstrate that Canadian interest rates are more affected by news on the United States economy than by that on the Canadian economy.

At the end, Ehrmann and Fratzscher (2002) analyse interdependence between the Euro area and the US area in the period 1993-2002 ${ }^{1}$. In particular, they examine how the release of macroeconomic news from the Euro area and US area can influence domestic interest rates and interest rates of the other area. The authors find some spillover effects from the USA into the Euro area, noting that we are in the presence of an increasing interdependence between these two areas. This interdependence appears very similar to what we shall call dependence.

\section{Expectations using futures}

The measurement of market expectations constitutes an important aspect of our analysis. It is well known that the measurement of expectations of future monetary policy decisions is rather complex. A broad ranging literature has grown in recent years on the use of asset prices to measure expectations.

Kuttner (2001) and Faust, Swanson and Wright (2001) use the current month Federal Funds futures contract to measure the expectations on the Federal Funds rate. Other authors like Bomfim (2003), Poole and Rasche (2000), and Poole, Rasche, and Thornton (2002) use the month-ahead Federal Funds futures contract.

\footnotetext{
${ }^{1}$ They use data from Bundesbank for the period 1993-1998.
} 
In 2002 Gurkaynak, Sack, and Swanson looked at the optimal marketbased measures of monetary policy expectations for up to five months. Their predictive power for the future Federal Funds rate is the highest. In 2004 Bernoth and von Hagen studied the efficiency of the three month Euribor futures markets, they found the Euribor future rates are an unbiased predictors of future spot rates.

Furthermore, Nosal (2001), Chernenko, Schwarz and Wright (2004), and Piazzesi and Swanson (2004) have checked the presence of a risk premium in the futures market, that can complicate the correspondence between the rate implied by the future price and the expected target rate. They find this risk premium to be relatively small for the short time horizons that will be used in this paper.

The approach we use to measure the expectation is similar to Poole, Rasche, and Thornton (2002).

The idea is to compute the difference between two appropriate future prices. This difference should represent the surprise generated by the monetary policy announcement.

Following this line, we can interpret the future price at time $t-1\left(f_{t-1}\right)$ as the conditional expectation (conditioned with respect to the information set $I)^{2}$ of the spot rate $(r)$ at the maturity date $(m)$.

$$
E\left[r_{m} \mid I_{t-1}\right]=f_{m, t-1}
$$

Then, the surprise $\left(\Delta r_{t}^{u}\right)$ will be given by the change in the conditional expectation:

$$
\Delta r_{t}^{u}=E\left[r_{m} \mid I_{t}\right]-E\left[r_{m} \mid I_{t-1}\right]=f_{m, t}-f_{m, t-1}
$$

Once we have a surprise generated by monetary policy decisions we can measure market's expectations $\left(\Delta r_{t}^{e}\right)$ as:

$$
\Delta r_{t}^{e}=\Delta r_{t}-\Delta r_{t}^{u}
$$

\footnotetext{
${ }^{2}$ Technically, the information set $I$ is a $\sigma$-field.
} 
where $\Delta r_{t}$ is the change in the interest rate operated by the monetary policy authority.

\section{The empirical models}

To investigate the presence of Central Bank leadership we estimate two different empirical models.

The first examines the impact of a Central Bank announcement on interest rates, while the second is used to study the possibility of international interdependence.

The first model we estimate is the model described by Cook and Hahn (1989) as improved by Kuttner (2001). The Cook and Hahn model consists of an OLS regression ${ }^{3}$ where the dependent variable is the one-day response ${ }^{4}$ of interest rates, and the independent variable is the change in the Fed Funds target. Kuttner (2001) uses Cook and Hahn's model adjusted for expectations. By using futures contracts as mentioned above, Kuttner splits the change in target into expected and unexpected monetary components. We estimate the following equation:

$$
\Delta R_{t}=\alpha+\beta_{1} \Delta r_{t}^{e}+\beta_{2} \Delta r_{t}^{u}+\varepsilon_{t}
$$

where $\mathrm{R}$ is the rate examined, $\beta$ is the response to expected and unexpected changes to the target.

In the model we estimate, $\Delta R$ is computed as the one-day response ${ }^{5}$ to monetary policy decision. In this way we can outline market's adjustment

\footnotetext{
${ }^{3}$ Poole, Rasche, Thornton (2002) underline that the use of the OLS method of estimation could give distorted results. The distortion is due to the different ways in which markets process new information. They nevertheless also affirm that the differences between estimates made using the OLS method and those made using the "errors in variable" method are generally very small.

${ }^{4}$ In actual fact the change is calculated between the rate on the day of the announcement and the rate on the following day.

${ }^{5}$ See the appendix for details about the timing of the fixing of the interest rate.
} 
after monetary policy decisions. In this way we can describe how the market adjusts after monetary policy decisions are made. The coefficient $\beta_{2}$ enables us to measure the interest rate response to the surprise component. This measure is very useful for understanding the reaction of operators to the impact of the new information contained in the monetary policy announcement, while $\beta_{1}$ "expected response" represents the market response to information already known by operators. This econometric exercise gives us indications of the ability of a Central Bank to control its yield curve and to analyse the behaviour of non-domestic markets in relation to the announcements of a Central Bank. We expect an $\alpha$ value very close to zero, a value for $\beta_{1}$ statistically not significant and close to zero, and a $\beta_{2}$ statistically significant and close to one. These theoretical results are obtained from the rational expectation model which postulates market responses to new information only.

To address the question of a possible dependence of interest rates on a Central Bank announcements more accurately, we estimate a second model. This specification is similar to the previous one, but in this case we run a multivariate regression. We run an OLS regression where the dependent variable is a one-day response of interest rates, while the exogenous variables are the surprises generated by two Central Bank announcements. In particular, when a Central Bank announces we have the surprise of this announcement, while the surprise generated by the other Central Bank (on this nonannouncements day) is by definition equal to zero.

The equation we estimate is

$$
\Delta R_{t}^{d}=\alpha+\beta_{1} \Delta r_{t}^{u, d}+\beta_{2} \Delta r_{t}^{u, o}+\varepsilon_{t}
$$

Where $\Delta R_{t}^{d}$ is the one-day return of the examined rate, $\Delta r_{t}^{u, d}$ is the surprise generated by the announcements of the "domestic" Central Bank at date $\mathrm{t}$, while $\Delta r_{t}^{u, o}$ is the surprise generated by the announcements of the "other" Central Bank at date t. 
Of course, $\Delta r_{t}^{u, o}$ is equal to zero when we have only the announcement of the "domestic" Central Bank at date t. On the contrary, $\Delta r_{t}^{u, d}$ is equal to zero when we have only the announcement of the "other" Central Bank at date t.

In other words, using this model we try to study the likelihood that the surprise measures are correlated even on non surprise days with the one-day interest rate response. In fact, $\Delta R_{t}^{d}$ should be correlated only with $\Delta r_{t}^{u, d}$ and it should not react to $\Delta r_{t}^{u, o}$.

As we can understand, we expect the interest rates respond to the "domestic" Central Bank's surprise more than the "other" Central Bank's surprise.

\section{The sample for the analysis}

The analysis covers the period 1st January 1999 through to 31st October 2005, and our data-set comes from DATASTREAM.

First of all, the analysis is based on the variations of prices (future prices or interest rates) on the relevant day. The difference between these prices, measured on the appropriate day, is relevant for detecting the new information given by the Central Bank announcement. As can be understood the timing of both the announcements and the fixing of the interest rates is very important ${ }^{6}$.

During the period covered by our analysis we have outlined the monetary policy meetings of the three Central Banks. It is important to note that we consider all meetings and not only those followed by a monetary policy change. This is justified by the fact that every meeting gives information that helps operators to form their expectations, influencing the trend of interest rates. In the period analysed the ECB had a greater number of meetings than the FED and the BoE (Table 1), the ECB had 117 meetings,

\footnotetext{
${ }^{6}$ In the appendix we write these important details.
} 
the FED 54, and the BoE $82^{7}$.

\section{Insert table 1 here}

In short, the youngest of the three Banks had more meetings than the others. We have to remember that the ECB had two meetings per month and in November 2001 the ECB Governing Council announced ${ }^{8}$ that -as a rule- it would assess its monetary policy stance only in the first meeting of the month. For this reason we have considered only the first meeting of the month since November 2001.

The ECB left its interest rates unchanged in $87.18 \%$ of those meetings, raised them by a half point in $1.71 \%$ and by a quarter of a point (percent) in $4.27 \%$ of meetings. It reduced them by a quarter of a point and by half a point respectively in $2.56 \%$ and $4.27 \%$ of the meetings.

The Federal Reserve left its interest rates unchanged in $50 \%$ of its meetings, raised them by half a point and by a quarter-point respectively in $1.85 \%$ and $29.63 \%$ of its meetings, and reduced them by a quarter-point and half-point respectively in $7.41 \%$ and $11.11 \%$ of its meetings. The Bank of England left its interest rates unchanged in $73.17 \%$ of its meetings, raised them by a quarter-point in $10.98 \%$ and it reduced them by a quarter-point and a half-point respectively in $13.41 \%$ and $2.44 \%$ of its meetings.

\section{The results}

We have divided the results of our analysis in two main parts: the first one concerns the first specification given by (3), while the second one concerns the second specification given by (4). The main econometric results are reported in Tables 2-7 for the equation (3), while for the equation (4) are reported in Tables 8-9. The estimates are expressed in percentage points.

\footnotetext{
${ }^{7}$ For the FED we use unscheduled meetings as well.

${ }^{8}$ See, http://www.ecb.int/press/pressconf/2001/html/is011108.en.html
} 
The p-values are obtained using the semiparametric-bootstrap method. In particular, we use 399 Bootstrap sample replications ${ }^{9}$.

All our estimates show that the effect of monetary policy varies across the maturity spectrum: it is larger for short-term rates, and diminishes with longer maturities. This finding confirms Cook and Hahn (1989), Rudebush (1995), Thornton (1998), Kuttner (2001), and it is well explained in Thornton (1998), and Thornton (2005).

\subsection{The results of the first specification}

Table 2 shows the response of short-term interest rates to ECB changes in MRO's on Euro, American, and British markets, while table 3 gives the response to BoE changes in repos on these markets and finally table 4 shows the response to FED changes in the federal fund target on the same markets.

As we can see in table 2, ranging from about 73 basis points to 82 basis points, the unexpected response of the Euro money market shows a significant reaction of the Euro interest rates to ECB announcements. By contrast, we observe the US rates do not react to ECB's announcements.

\section{Insert table 2 here}

The results for relations between the ECB's decisions and the British money market are interesting. There is a reaction by the British interbank interest rate to ECB announcements. A good explanation may be that the ECB's meetings and the BoE's meetings are often on the same days. From 2002:01:01 to 2005:10:31, 45 ECB's meetings, 29 happened on the same days as those of the BoE, and 19 meetings were followed by the same decisions ${ }^{10}$.

\footnotetext{
${ }^{9}$ This procedure leads to a p-value which is more accurate than the usual p-value, see Davidson, R., MacKinnon, J., 2004.

${ }^{10}$ Clearly this coincidence in the dates affects the estimates made. It must nevertheless be underlined that in the 19 meetings in which the ECB and the BoE took the same decision, this always coincided with leaving interest rates unchanged. On the contrary, in the other 10 meetings, rates were changed, but always by a different amount.
} 
Table 3 shows the impact of the BoE.

\section{Insert table 3 here}

The Bank of England seems able to control its yields curve up to a maturity of one year. The influence of the BoE's decisions is stronger on the LIBOR one year than on the LIBOR 1 month rate. Of course, it is possible to explain this by recalling that the BoE does not use a specific target for the shorter interest rates, preferring to focus on the longer one. Euro interest rates appear sensitive to the BoE's monetary policy decisions. Both Euribor one-month and one-year interest rates show a ready response to the unexpected monetary policy change. Again the coincidence of BoE and ECB's meetings may be relevant. As for the ECB, the US rates do not react to BoE's announcements.

Finally, consider the Federal Reserve from Table 4.

\section{Insert table 4 here}

First of all, as we would expect both the one month and one year US interbank interest rates react to FED announcements strongly. In particular, we see that short term interest rates reflect the variation announced almost entirely (the coefficient of unexpected response is approximately equal to one), while the longer money market interest rates (one year) respond much less. These results, of course, are similar to the results obtained by Kuttner (2001), and Poole, Rasche, and Thornton (2002).

The reaction of Euro interest rates to the FED's announcements appears statistically significant, with an intercept and an "expected response" close to zero and an unexpected response close to 0.24 for Euribor one month rate, which increases up to 0.56 for Euribor 1 year rate. In other words, it seems to increase the influence of the FED announcements with the maturity of the interest rate considered. The same thing cannot be said about the British market. The British rates do react to FED announcements but to a much lesser extent. 
Concerning possible spillover effects from FED to other markets, Euro interest rates do indeed react to the FED announcements, but not apparently to British announcements.

Having examined the response of monetary markets to the monetary policy announcements of the three Central Banks under study here, we will now focus on an analysis of the longer term markets, those of bonds. As is known, the rates that are set in those markets constitute indicators used by many economic operators in their decision making.

It would seem plausible to expect each bank to control the time structure of its own rates and therefore Euro, US, and British market rates should respond principally to the announcements of the ECB, FED and the BoE respectively and only marginally to other announcements.

The results of this analysis are given in tables 5,6 and 7 . Table 5 shows the response of interest rates to ECB changes in MRO on Euro, American, and British markets, while table 6 gives the response to $\mathrm{BoE}$ changes in repos on these markets and finally table 7 shows the response to FED changes in the federal fund target on the same markets.

As with the analysis of money markets, we expect that the intercept and expected response coefficients are approximately equal to zero or statistically not significant. This confirms that interest rates only respond to new elements in the monetary policy announcements.

\section{Insert table 5 here}

Examination of table 5 shows that the unexpected response to ECB's announcements for 2, 5, and 10 year rates in the euro area is statistically significant. This coefficient becomes rapidly less significant with longer term maturity dates, which leads to the conclusion that the ECB has a degree of influence on the time structure of its rates up to maturities of 10 years. The ECB's decisions seem to have an irrelevant impact on interest rates in the American bond market, because the estimates show a low $\mathrm{R}$ square, and the p-values of the estimated coefficients are not significant at least 
at the usual 5\% level. On the contrary, the British market reacts to ECB announcements. Again, the fact that ECB meetings and BoE meetings are often on the same days could be the main reason. Another reason is that the Great Britain has not yet decided to enter the EMU and the expectation on that decision can play a role in explaining why operators listen to ECB announcements.

\section{Insert table 6 here}

The same analysis of table 6 shows that the BoE also effectively moves the time structure of its interest rates up to maturities of 30 years and here too the unexpected response coefficient is fairly substantial, especially for 2 and 5 year rates. As with the ECB announcements BoE decisions seem to have an irrelevant impact on interest rates in the American bond market. On the contrary, the Euro responds to the BoE's decisions, and as before, the main reason could be that the BoE's meetings and the ECB's meeting are often on the same days.

\section{Insert table 7 here}

If we now look at table 7, which shows the role of FED announcements on the Euro, British and American markets, we see rather interesting results. First of all, the results of our estimation of the impact of FED announcements on the American bond market are very similar to Kuttner (2001), and Poole, Rasche, and Thornton (2002). With respect to Kuttner we find a slightly greater unexpected response for all maturities, and this is due to both the different period considered and the slightly different way of computing the expectations. As can be seen from our estimates, the American bond market reacts to FED announcements up to maturities of 30 years strongly, but surprisingly, interest rates on the Euro market also react to FED announcements considerably. The unexpected response coefficient for 2 and 5 year rates is 0.8 and 0.66 approximately, while for the 10 year rate it is 0.51 approximately. This coefficient decreases slightly for 20 to 30 year 
maturity rates, but still continues to be significant for the 30 year maturity rate.

Rates on British markets respond to FED intervention, with an unexpected response coefficient of 0.77 for the two year rate, of 0.51 for the 5 year rate, while it is not significant for maturities between 10 and 30 years.

The results that emerge from this comparative analysis are therefore extremely interesting. While it is true that the ECB and the BoE control the time structure of their own rates fairly significantly up to 5 years, it is also true that the FED not only controls the same rates up to almost 30 years for the Euro, but these rates seem to respond more strongly to FED announcements than they do to those of the ECB. While the British market, on the other hand, responds to FED announcements for the 2 and 5 year maturity, the impact of FED announcements is quite similar to those of the BoE. Moreover, the impact of FED announcements is limited to these maturities while the impact of BoE announcements remains significant up to 30 year maturity.

In brief, what seems to emerge is a dependence of Euro bond rates on FED announcements while this is less evident for the British bond market. We may find further evidence using the results of the next subsection.

\subsection{The results of the second specification}

From the previous subsection, we have obtained some evidence in favour of a FED leadership on European rates. This leadership seems to be stronger for Euro rates than the British rates. In order to study this FED's leadership both on Euro markets and British market we run two separate regressions. In the first one, we use the FED's surprise and the ECB's surprise to explain the response of Euro interest rates and for the second one, we use FED's surprises and the BoE's surprises to explain the response of British interest rates. In other words, we try to study the FED's surprise as a determinant of the Euro and British interest rates response. 
Furthermore, we choose to make this vis à vis comparison to account for announcements being made on the same day, and this fact is relevant for the ECB and BoE meetings, while it is irrelevant for the other meetings. Of course, we do not consider the American market because we do not find any response of US's rates to ECB and BoE announcements from the previous specifications.

We leave the analysis of the relation between ECB and BoE announcements on EMU and British market for further research, mainly because these relations are complicated by two reasons. The first is that, as outlined above, many ECB meetings happened on the same days as BoE meetings and of course this can create confusion in deciding whether the market actually responds to ECB or BoE decisions. The second is that Great Britain has not yet decided to enter the EMU, and expectations of this decision may play an important role.

The econometric result of the estimates of equation (4) are reported in Table 8 and in Table 9. As outlined above, we estimate the equation (4) to study the likelihood that the surprise measures are correlated even on nonsurprise days with the one-day response of the interest rates, and in this way to get evidence of interdependence (dependence) effect.

\section{Insert Table 8 here}

As can be seen from Table 8, Euro interest rates react to the surprise component of ECB monetary policy announcements up to 10 year maturities, at least at the usual 5\% level. But surprisingly and more important, there is a significant response for all maturities considered at the usual $5 \%$ level for the response of interest rates to the surprise component of FED announcements, and this response is stronger than the ECB's surprise for all maturities ranging from 2 year to 30 year.

\section{Insert Table 9 here}


Looking at Table 9, we find evidence that the British interest rates do not react to the FED's surprise announcements. The coefficients of the reaction of UK interest rates to BoE's surprise announcements are significant and greater than the correspondent coefficients of FED's surprise announcements. Furthermore the latter are never significant at the $5 \%$ level.

Clearly, these results are further and strong evidence of a dependence of Euro interest rates on FED announcements, while the same cannot be said of British interest rates.

\section{Conclusion}

This study analyses, for the first time, the reactions of markets to the monetary policy decisions of their own Central Bank and to the decisions of the Central Banks of other countries. We find three distinct situations. The first reveals that American rates respond to FED monetary decisions only; the second shows that British rates respond mainly to BoE monetary announcements and only marginally to FED announcements for both monetary and bond market rates. Finally the third situation demonstrates that rates in the monetary market respond to ECB announcements, while bond markets respond mainly to FED announcements and only marginally to ECB announcements ${ }^{11}$.

The reasons for this FED leadership are certainly multiple and not always easy to identify. One initial reason could, however, be connected with market size. The American market is decidedly larger than the Euro and British markets in terms of volumes traded. It would therefore be plausible to expect that financial operators have a greater interest in and take more account of events on that market.

A second factor that may explain FED leadership could be closely linked

\footnotetext{
${ }^{11}$ This also confirms the findings of Breuss F. (2002) who found a causal relationship between the FED's monetary decisions and those of the ECB. Accordingly, the ECB follows those of the FED with a lag of 4-6 months.
} 
with the communication strategies ${ }^{12}$ adopted by Central Banks. When a Central Bank makes a monetary policy change, it officially announces its decisions to the market. The methods adopted by the Central Bank for making the communication are very important because they help shape the expectations of market operators.

As is known, in recent years Central Banks have tended to implement policies by transparently manifesting their intentions in advance to some degree. This transparency helps increase the ability of operators to understand the decisions of the monetary authority, which improves the effectiveness of the monetary decision. Jansen and de Haan (2004) claim that ECB statements were rather contradictory in this respect in its first few years ${ }^{13}$. While its statements on interest rates have become more consistent in recent years, its statements on growth and inflation are still ambiguous.

A third element, strictly connected with the previous one, is the reputation of the bank itself. This reputation is a direct function of the Central Bank's ability to pursue the monetary policy objectives that it sets itself. Financial operators could therefore place their trust in the good reputation of the FED, while they are still unable to judge the ability of the ECB. The $\mathrm{ECB}$ is in fact too young for operators to be able to express an opinion on its ability to achieve the monetary policy objectives it sets itself, especially in the long term.

While the ECB's reputation is young, the same cannot be said of the $\mathrm{BoE}$, which is the oldest Central Bank in the world. Looking at the results, the $\mathrm{BoE}$ does not seem to be subject to FED leadership: the BoE demonstrates that it knows how to adjust its rates, which are not very sensitive to FED announcements.

\footnotetext{
${ }^{12}$ The fact that the FED today is discussing the adoption of targets (Wang, J., 2005), when Greenspan retires, seems to underline the importance of the reputation and communicative skills of the current FED chairman.

${ }^{13}$ See also Padoa-Schioppa 2004 on ECB communication problems.
} 
Finally, the Euro and British financial markets are in a situation which will not become final for a few years to come. While on the one hand financial integration in the EMU area is not yet complete, on the other hand Great Britain has not yet decided to enter the EMU. It is possible, in such a context, that operators are more interested in basing their decisions on the FED which operates on a decidedly more stable market.

\section{Acknowledgements}

We are indebted to Daniel Thornton for very useful comments; we also thank Angelo Baglioni, James Davidson, Kenneth Kuttner, Peter M. Oppenheimer, and Raffaella Piemonte for their help. The responsibility for any remaining errors is only ours.

\section{Appendix}

\section{Data sources}

The time series of the interest rates are for Euro the Euribor one month and one year both are fixed at 10:00 (GMT). The bond data for all markets are always the end-of-day yields of on-the-run Treasuries. To measure the expectation we use data ${ }^{14}$ from the future prices on the three month Euribor, which has a daily settlement calculated at 18:00 (GMT), except on the last trading day when it is at 10:00 (GMT). However, in our analysis we use the continuous series type CS00 (DATASTREAM Code). This series always rolls before the contract has expired; so for the future on Three month Euribor the price is always fixed at 18:00 (GMT). The future price does not reflect the announcement of any policy changes made after that time.

For the British market both the LIBOR one month and one year are fixed at 11:00 (GMT). To measure the expectation we use the future prices

\footnotetext{
${ }^{14}$ Our data-set comes from DATASTREAM. The code for the three month Euribor future is GQECS00; the code for the three month sterling interest rate future is LIPCS00; the code for the federal funds future is CFFCS00.
} 
on the Three Month Sterling (Short Sterling) Interest Rate contract which has the daily settlement price calculated at 16:09 (GMT), except on the Last Trading Date when it is calculated at 11:00 GMT. Also in this case, we use the continuous series type CS00 (DATASTREAM Code). This series always rolls before the contract has expired so for the future on the Three Month Sterling the price is always fixed at 16:09 (GMT). The future price does not reflect the announcement of any policy changes made after that time.

For the American market both the US interbank one month and one year are fixed at 11:00 (GMT). To measure the expectation we use the onemonth Federal Funds future prices ${ }^{15}$ which has a settlement price calculated at 19:00 (GMT).

\section{Timing Issues}

The timing is a very important aspect when working with daily data, and this is particularly true in our study.

The decisions on the key interest rates for the euro area are announced in a press release issued at 13:45 C.E.T. (12:45 GMT) on the day of the Governing Council's first meeting of the month. For the BoE the decisions of the Monetary Policy Committee are announced at 12 noon (GMT). Normally, for the FED the announcement comes at roughly 13:15 pm Easter time (18:15 GMT).

\section{References}

[1] Bernoth, K., von Hagen, J., 2004. The Euribor Futures Market: Efficiency and the impact of ECB Policy Announcements. International Finance, 7:1, 1-24.

\footnotetext{
${ }^{15}$ In this case we use the future with expiration one-month ahead. For that reason we do not use the so-called scaling factor.
} 
[2] Bomfim, A., 2003. Pre-Announcement Effects, News Effects, and Volatility: Monetary Policy and the Stock Market. Journal of Banking and Finance, Vol. 27, Issue 1, January, 133-151.

[3] Breuss, F., 2002. Was ECB's Monetary Policy optimal?. Atlantic Economic Journal, Vol. 30, No. 3, September, 298-319.

[4] Cook, T., Hahn, T., 1989. The effect of changes in the Federal funds rate target on market interest rates in the 1970s. Journal of Monetary Economics, year 24, 331-351.

[5] Chernenko, S., Schwarz K., Wright, J., 2004. The information Content of Forward and Futures Prices: Market Expectations and the Price of Risk. International Finance Discussion Paper, Board of Governors of the Federal Reserve, No. 808.

[6] Davidson, R., MacKinnon, J., 2004. Econometric Theory and Methods, Oxford University press, New York.

[7] ECB, 2001. ECB Press Conference: Introductory Statement, November 8th 2001. Frankfurt. (http://www.ecb.int/press/pressconf/2001/html/is011108.en.html)

[8] Edelberg, W., Marshall, D., 1996. Monetary policy shocks and longterm interest rates. Federal Reserve Bank of Chicago Economic Perspectives, 20, 2-17.

[9] Ehrmann, M., Fratzscher, M., 2002. Interdependence between the Euro Area and the US: What Role for EMU?. ECB Working Paper No 200.

[10] Faust, J., Swanson, E., Wright, J. H., 2001. Identifying VARs Based on High Frequency Futures Data. International Finance Discussion Papers No. 720, Board of Governors of the Federal Reserve System. 
[11] Gravelle, T., Moessner, R., 2001. Reactions of Canadian Interest Rates to Macroeconomic Announcements: Implications for Monetary Policy Transparency. Working Paper Bank of Canada, n. 01-05.

[12] Gürkaynak, R. S., Sack, B., Swanson, E., 2002. Market-Based Measures of Monetary Policy Expectations. Board of Governors of the Federal Reserve System (U.S.). Finance and Economics Discussion Series n. 40.

[13] Jansen, D., de Haan, J., 2004. Look who's talking: ECB communication during the first year of EMU. CESifo Working Paper series, n. 1263.

[14] Kim, S., Kortian, T., Sheen, J., 2000. Central bank intervention and exchange rate volatility. Australian evidence. Journal of International Financial Markets, Insitutions and Money, n. 10(4), 385-405.

[15] Kuttner, K.N., 2001. Monetary policy surprise and interest rates: Evidence from the Fed funds futures market. Journal of Monetary Economics, 47, No 3, 523-544.

[16] Nosal, E., 2001. How well Does the Fedearl Funds Future Rate Predict the Future Federal Funds Rate?, Federal Reserve Bank of Cleveland, Economic Commentary, October, 1-4.

[17] Padoa-Schioppa, T., 2004. Interview in Wall Street Journal, 15 July.

[18] Perez-Quiros, G., Sicilia, J., 2002. Is the European Central Bank (and the United States Federal Reserve) predictable?. ECB Working Paper No 192.

[19] Piazzesi, M., Swanson, E., 2004. Future Prices as Risk-Adjusted Forecasts of Monetary Policy, National Bureau of Economic Research Working Paper, No. 10547.

[20] Poole, W., Rasche, R. H., 2000. Perfecting the Market's Knowledge of Monetary Policy. Journal of Financial Services Research,. 255-298. 
[21] Poole, W., Rasche, R. H., Thornton, D. L., 2002. Market Anticipations of Monetary Policy Actions. Federal Reserve Bank of St. Louis Review, July-August, 65-94.

[22] Roley, V.V., Sellon, G.H., 1995. Monetary policy action and long term interest rats. Federal Reserve Bank of Kansas City. Economic Quarterly $80,77-89$.

[23] Ross, K., 2002. Market Predictability of ECB Policy Decisions: A Comparative Examination. IMF Working Paper.

[24] Rudebusch, G., 1995. Federal Reserve Interest Rate Targeting, Rational Expectations, and the Term Structure. Journal of Monetary Economics, 39(4), 245-274.

[25] Thornton, D. L., 1998. Tests of the market's reaction to Federal funds rate target changes. Federal Reserve Bank of St. Louis Review, November/December, 80(6), 25-36.

[26] Thornton, D. L., 2005. Predictions of Short-Term Rates and the Expectations Hypothesis of the Term Structure of Interest Rates, Federal Reserve Bank of St. Louis Working Paper, 2004-010A .

[27] Wang, J., 2005. Inflation Targeting. Region Focus Federal Reserve Bank of Richmond, 2-4. 
Table 1: Number of meetings and decisions

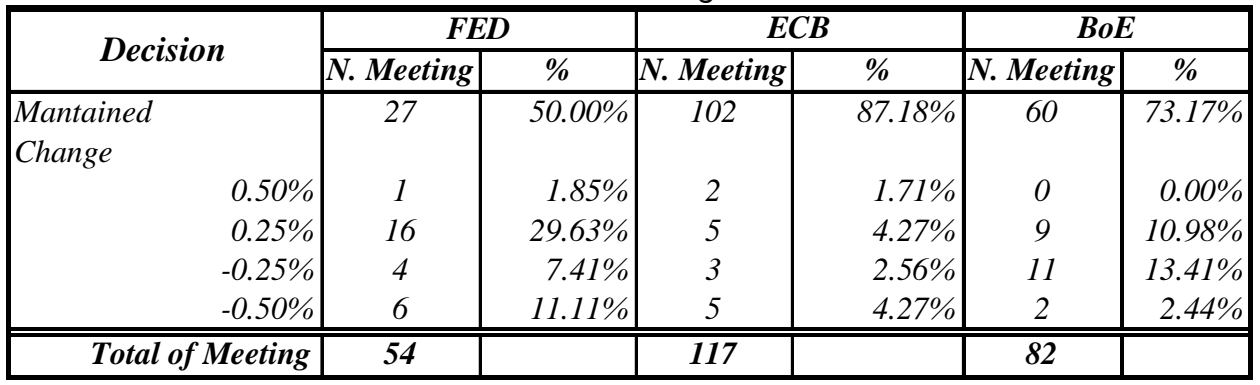

Table 2: The Response of Interest Rates to ECB's decisions.

\begin{tabular}{|c|c|c|c|c|c|}
\hline \multicolumn{6}{|c|}{ The 1-day response of interest rates to changes in the MRO } \\
\hline & Intercept & $\begin{array}{l}\text { Response } \\
\text { Expected }\end{array}$ & $\begin{array}{c}\text { Response } \\
\text { Unexpected }\end{array}$ & $\mathrm{R}^{\wedge} 2$ & DW \\
\hline \multirow[t]{2}{*}{ Euribor 1 month } & -0.001 & 0.091 & 0.732 & \multirow{2}{*}{0.426} & \multirow{2}{*}{2.082} \\
\hline & 0.636 & 0.12 & 0 & & \\
\hline \multirow[t]{2}{*}{ Euribor 12 month } & 0.003 & 0.044 & 0.817 & \multirow{2}{*}{0.626} & \multirow{2}{*}{2.028} \\
\hline & 0.292 & 0.1 & 0 & & \\
\hline \multirow{2}{*}{$\begin{array}{l}\text { US Interbank } 1 \text { month } \\
\qquad p \text {-value }\end{array}$} & -0.003 & 0.039 & 0.204 & \multirow{2}{*}{0.04} & \multirow{2}{*}{2.01} \\
\hline & 0.275 & 0.11 & 0.165 & & \\
\hline \multirow{2}{*}{$\begin{array}{l}\text { US Interbank } 12 \text { month } \\
\qquad p \text {-value }\end{array}$} & -0.007 & 0.027 & -0.229 & \multirow{2}{*}{0.016} & \multirow{2}{*}{1.689} \\
\hline & 0.101 & 0.38 & 0.365 & & \\
\hline \multirow[t]{2}{*}{ LIBOR 1 month } & -0.004 & 0.035 & 0.609 & \multirow{2}{*}{0.315} & \multirow{2}{*}{2.04} \\
\hline & 0.131 & 0.15 & 0 & & \\
\hline \multirow[t]{2}{*}{ LIBOR 12 month } & 0 & 0.02 & 0.905 & \multirow{2}{*}{0.573} & \multirow{2}{*}{2.015} \\
\hline & 0.838 & 0.464 & 0 & & \\
\hline
\end{tabular}

Notes: p-value from 399 bootstrap replications and Eicker and White Standard error, the estimates are expressed in percentage points. 
Table 3: The Response of Interest Rates to BoE's decisions.

\begin{tabular}{|c|c|c|c|c|c|}
\hline \multicolumn{6}{|c|}{ The 1-day response of interest rates to changes in the repo rate } \\
\hline & Intercept & $\begin{array}{l}\text { Response } \\
\text { Expected }\end{array}$ & $\begin{array}{c}\text { Response } \\
\text { Unexpected }\end{array}$ & $\mathrm{R} \wedge 2$ & DW \\
\hline \multirow[t]{2}{*}{ Euribor 1 month } & -0.001 & 0.053 & 0.782 & \multirow{2}{*}{0.405} & \multirow{2}{*}{2.178} \\
\hline & 0.656 & 0.1 & 0 & & \\
\hline \multirow[t]{2}{*}{ Euribor 12 month } & 0.002 & 0.007 & 0.986 & \multirow{2}{*}{0.821} & \multirow{2}{*}{2.018} \\
\hline & 0.252 & 0.626 & 0 & & \\
\hline \multirow{2}{*}{$\begin{array}{r}\text { US Interbank } 1 \text { month } \\
p \text {-value } \\
\end{array}$} & -0.001 & 0.006 & -0.16 & \multirow{2}{*}{0.007} & \multirow{2}{*}{1.837} \\
\hline & 0.859 & 0.827 & 0.691 & & \\
\hline \multirow{2}{*}{$\begin{array}{r}\text { US Interbank } 12 \text { month } \\
p \text {-value }\end{array}$} & 0 & 0.018 & 0.641 & \multirow{2}{*}{0.04} & \multirow{2}{*}{2.165} \\
\hline & 0.822 & 0.541 & 0.12 & & \\
\hline \multirow[t]{2}{*}{ LIBOR 1 month } & -0.005 & 0.2 & 0.922 & \multirow{2}{*}{0.662} & \multirow{2}{*}{1.809} \\
\hline & 0.3 & 0.1 & 0 & & \\
\hline \multirow[t]{2}{*}{ LIBOR 12 month } & 0.006 & 0.016 & 1.06 & \multirow{2}{*}{0.776} & \multirow{2}{*}{1.868} \\
\hline & 0.131 & 0.555 & 0 & & \\
\hline
\end{tabular}

Notes: p-value from 399 bootstrap replications and Eicker and White Standard error, the estimates are expressed in percentage points.

Table 4: The Response of Interest Rates to FED's decisions.

The 1-day response of interest rates to changes in the Fed funds target

\begin{tabular}{|c|c|c|c|c|c|}
\hline & Intercept & $\begin{array}{l}\text { Response } \\
\text { Expected }\end{array}$ & $\begin{array}{c}\text { Response } \\
\text { Unexpected }\end{array}$ & $\mathrm{R}^{\wedge} 2$ & DW \\
\hline \multirow[t]{2}{*}{ Euribor 1 month } & -0.004 & 0.048 & 0.239 & \multirow{2}{*}{0.397} & \multirow{2}{*}{2.197} \\
\hline & 0.111 & 0.123 & 0 & & \\
\hline \multirow[t]{2}{*}{ Euribor 12 month } & -0.002 & 0.041 & 0.555 & \multirow{2}{*}{0.443} & \multirow{2}{*}{1.906} \\
\hline & 0.536 & 0.222 & 0 & & \\
\hline \multirow{2}{*}{$\begin{array}{l}\text { US Interbank } 1 \text { month } \\
p \text {-value }\end{array}$} & -0.002 & 0.006 & 0.999 & \multirow{2}{*}{0.791} & \multirow{2}{*}{1.8} \\
\hline & 0.456 & 0.669 & 0 & & \\
\hline \multirow{2}{*}{$\begin{array}{r}\text { US Interbank } 12 \text { month } \\
p \text {-value }\end{array}$} & -0.003 & 0.066 & 0.769 & \multirow{2}{*}{0.37} & \multirow{2}{*}{2.37} \\
\hline & 0.631 & 0.199 & 0 & & \\
\hline \multirow[t]{2}{*}{ LIBOR 1 month } & -0.004 & 0.02 & 0.23 & \multirow{2}{*}{0.122} & \multirow{2}{*}{2.252} \\
\hline & 0.141 & 0.161 & 0.02 & & \\
\hline \multirow[t]{2}{*}{ LIBOR 12 month } & 0 & 0.019 & 0.3 & \multirow{2}{*}{0.105} & \multirow{2}{*}{2.14} \\
\hline & 0.989 & 0.424 & 0 & & \\
\hline
\end{tabular}

Notes: p-value from 399 bootstrap replications and Eicker and White Standard error, the estimates are expressed in percentage points. 
Table 5: The Response of Interest Rates to ECB's Decisions.

\begin{tabular}{|c|c|c|c|c|c|}
\hline \multicolumn{6}{|c|}{ The 1-day response of interest rates to changes in the MRO } \\
\hline $\begin{array}{c}\text { Maturity } \\
\text { EMU }\end{array}$ & Intercept & $\begin{array}{l}\text { Response } \\
\text { Expected }\end{array}$ & $\begin{array}{c}\text { Response } \\
\text { Unexpected }\end{array}$ & $\mathrm{R} \wedge 2$ & DW \\
\hline \multirow[t]{2}{*}{2 year } & 0.003 & 0.008 & 0.805 & \multirow{2}{*}{0.396} & \multirow{2}{*}{2.147} \\
\hline & 0.510 & 0.848 & 0.000 & & \\
\hline \multirow[t]{2}{*}{5 year } & 0 & -0.035 & 0.592 & \multirow{2}{*}{0.269} & \multirow{2}{*}{1.92} \\
\hline & 0.828 & 0.373 & 0.000 & & \\
\hline \multirow[t]{2}{*}{10 year } & -0.003 & -0.055 & 0.335 & \multirow{2}{*}{0.165} & \multirow{2}{*}{1.859} \\
\hline & 0.373 & 0.090 & 0.000 & & \\
\hline \multirow[t]{2}{*}{20 year } & -0.011 & -0.007 & 0.112 & \multirow{2}{*}{0.017} & \multirow{2}{*}{2.26} \\
\hline & 0.090 & 0.797 & 0.202 & & \\
\hline \multirow[t]{2}{*}{30 year } & -0.01 & -0.04 & 0.127 & \multirow{2}{*}{0.036} & \multirow{2}{*}{1.799} \\
\hline & 0.100 & 0.242 & 0.101 & & \\
\hline $\begin{array}{c}\text { Maturity } \\
\text { US }\end{array}$ & Intercept & $\begin{array}{l}\text { Response } \\
\text { Expected }\end{array}$ & $\begin{array}{c}\text { Response } \\
\text { Unexpected }\end{array}$ & $\mathrm{R}^{\wedge} 2$ & DW \\
\hline \multirow[t]{2}{*}{2 year } & 0 & -0.038 & -0.014 & \multirow{2}{*}{0.006} & \multirow{2}{*}{2.165} \\
\hline & 0.99 & 0.363 & 0.979 & & \\
\hline \multirow{2}{*}{5 year } & 0.001 & -0.058 & 0.141 & \multirow{2}{*}{0.015} & 2210 \\
\hline & 0.767 & 0.151 & 0.747 & & \\
\hline 10 year & -0.002 & -0.076 & 0.28 & ברח & 2293 \\
\hline$p$-value & 0.729 & 0.125 & 0.428 & $0.0<3$ & 2.250 \\
\hline 20 year & 0 & -0.055 & -0.179 & 0019 & 2232 \\
\hline$p$-value & 0.882 & 0.160 & 0.488 & & \\
\hline 30 year & 0 & -0.05 & -0.226 & 0019 & 2159 \\
\hline$p$-value & 0.979 & 0.172 & 0.408 & & \\
\hline $\begin{array}{c}\text { Maturity } \\
\text { UK }\end{array}$ & Intercept & $\begin{array}{l}\text { Response } \\
\text { Expected } \\
\end{array}$ & $\begin{array}{c}\text { Response } \\
\text { Unexpected }\end{array}$ & $\mathrm{R} \wedge 2$ & DW \\
\hline 2 year & 0 & 0.004 & 0.87 & 0518 & 1986 \\
\hline p-value & 0.696 & 0.888 & 0.000 & & \\
\hline 5 year & 0.004 & 0.011 & 0.655 & 0.32 & 2090 \\
\hline p-value & 0.282 & 0.66 & 0.000 & & \\
\hline 10 year & 0.006 & 0.01 & 0.454 & 0.147 & 2066 \\
\hline$p$-value & 0.171 & 0.797 & 0.000 & & \\
\hline 20 year & 0.002 & 0.003 & 0.311 & 0.09 & 1923 \\
\hline p-value & 0.464 & 0.929 & 0.000 & & \\
\hline 30 year & 0.001 & 0.002 & 0.257 & 0065 & 1903 \\
\hline p-value & 0.616 & 0.969 & 0.000 & & \\
\hline
\end{tabular}

Notes: p-value from 399 bootstrap replications and Eicker and White Standard error, the estimates are expressed in percentage points. 
Table 6: The Response of Interest Rates to BoE's Decisions.

\begin{tabular}{|c|c|c|c|c|c|}
\hline \multicolumn{6}{|c|}{ The 1-day response of interest rates to changes in the repo rate } \\
\hline $\begin{array}{c}\text { Maturity } \\
E M U\end{array}$ & Intercept & $\begin{array}{l}\text { Response } \\
\text { Expected }\end{array}$ & $\begin{array}{c}\text { Response } \\
\text { Unexpected }\end{array}$ & $\mathrm{R}^{\wedge} 2$ & DW \\
\hline \multirow[t]{2}{*}{2 year } & 0.004 & -0.012 & 0.948 & \multirow{2}{*}{0.464} & \multirow{2}{*}{2.23} \\
\hline & 0.353 & 0.767 & 0.000 & & \\
\hline \multirow[t]{2}{*}{5 year } & 0.001 & -0.06 & 0.726 & \multirow{2}{*}{0.371} & \multirow{2}{*}{2} \\
\hline & 0.818 & 0.121 & 0.000 & & \\
\hline \multirow[t]{2}{*}{10 year } & 0 & -0.056 & 0.457 & \multirow{2}{*}{0.206} & \multirow{2}{*}{2.23} \\
\hline & 0.535 & 0.101 & 0.000 & & \\
\hline \multirow[t]{2}{*}{20 year } & 0 & -0.071 & 0.104 & \multirow{2}{*}{0.061} & \multirow{2}{*}{2.388} \\
\hline & 0.989 & 0.09 & 0.343 & & \\
\hline \multirow[t]{2}{*}{30 year } & 0 & -0.1 & 0.25 & \multirow{2}{*}{0.151} & \multirow{2}{*}{2.089} \\
\hline & 0.222 & 0.010 & 0.130 & & \\
\hline $\begin{array}{c}\text { Maturity } \\
\text { US }\end{array}$ & Intercept & $\begin{array}{l}\text { Response } \\
\text { Expected }\end{array}$ & $\begin{array}{c}\text { Response } \\
\text { Unexpected }\end{array}$ & $\mathrm{R}^{\wedge} 2$ & DW \\
\hline \multirow[t]{2}{*}{2 year } & 0.008 & -0.053 & -0.177 & \multirow{2}{*}{0.02} & \multirow{2}{*}{2.144} \\
\hline & 0.223 & 0.258 & 0.395 & & \\
\hline \multirow{2}{*}{5 year } & 0.007 & -0.0755 & -0.02 & \multirow{2}{*}{0.023} & \multirow{2}{*}{2.307} \\
\hline & 0.350 & 0.165 & 0.899 & & \\
\hline 10 year & 0.008 & -0.083 & 0.017 & 02 & 2400 \\
\hline$p$-value & 0.243 & 0.14 & 0.942 & 0.3 & 2.405 \\
\hline 20 year & 0.009 & -0.069 & 0.046 & 0.02 & 2.704 \\
\hline$p$-value & 0.135 & 0.165 & 0.837 & & \\
\hline 30 year & 0.009 & -0.055 & 0.081 & 0.02 & 2653 \\
\hline p-value & 0.120 & 0.215 & 0.700 & & \\
\hline $\begin{array}{c}\text { Maturity } \\
U K \\
\end{array}$ & Intercept & $\begin{array}{l}\text { Response } \\
\text { Expected } \\
\end{array}$ & $\begin{array}{c}\text { Response } \\
\text { Unexpected }\end{array}$ & $\mathrm{R}^{\wedge} 2$ & DW \\
\hline 2 year & -0.001 & -0.038 & 0.726 & 0.587 & 1858 \\
\hline$p$-value & 0.666 & 0.303 & 0.000 & & \\
\hline 5 year & 0.002 & -0.095 & 0.462 & 0.371 & 1.676 \\
\hline$p$-value & 0.646 & 0.1 & 0.000 & & \\
\hline 10 year & 0.003 & -0.116 & 0.232 & 0.175 & 1680 \\
\hline$p$-value & 0.535 & 0.113 & 0.010 & & \\
\hline 20 year & 0.003 & -0.095 & 0.17 & 0.128 & 1.685 \\
\hline$p$-value & 0.444 & 0.099 & 0.040 & $0.1 \angle 0$ & 1.005 \\
\hline 30 year & 0.004 & -0.094 & 0.151 & 0.119 & 1.694 \\
\hline$p$-value & 0.393 & 0.070 & 0.050 & & \\
\hline
\end{tabular}

Notes: p-value from 399 bootstrap replications and Eicker and White Standard error, the estimates are expressed in percentage points. 
Table 7: The Response of Interest Rates to FED's Decisions.

The 1-day response of interest rates to changes in the Fed funds target

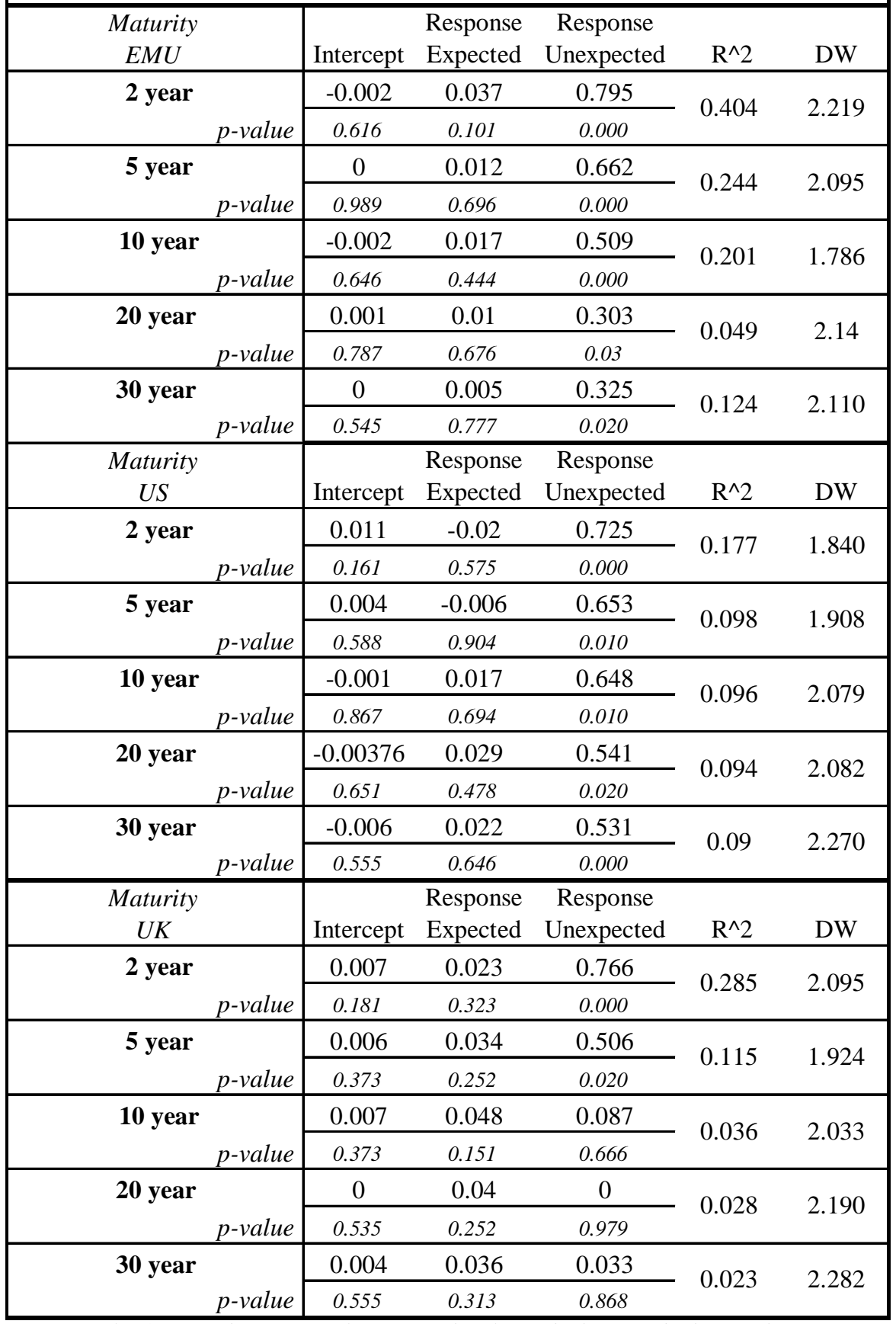

Notes: p-value from 399 bootstrap replications and Eicker and White Standard error, the estimates are expressed in percentage points. 
Table 8: The Response of EMU Interest Rates to ECB's and FED's surprise.

\begin{tabular}{|c|c|c|c|c|c|}
\hline \multicolumn{6}{|c|}{ The 1-day response of EMU interest rates to ECB's and FED's surprise } \\
\hline & Intercept & $\begin{array}{l}\text { Response } \\
\text { ECB } \\
\text { Surprise }\end{array}$ & $\begin{array}{l}\text { Response } \\
\text { FED } \\
\text { Surprise }\end{array}$ & $\mathrm{R} \wedge 2$ & DW \\
\hline \multirow[t]{2}{*}{ Interbank 1 month } & -0.003 & 0.71 & 0.262 & \multirow{2}{*}{0.376} & \multirow{2}{*}{2.187} \\
\hline & 0.363 & 0 & 0 & & \\
\hline \multirow{2}{*}{\begin{tabular}{|} 
Interbank 12 month \\
$p$-value \\
\end{tabular}} & 0.001 & 0.806 & 0.571 & \multirow{2}{*}{0.581} & \multirow{2}{*}{1.862} \\
\hline & 0.626 & 0 & 0 & & \\
\hline 2 year & 0.001 & 0.803 & 0.809 & \multirow{2}{*}{0.39} & \multirow{2}{*}{1.942} \\
\hline$p$-value & 0.707 & 0 & 0 & & \\
\hline \multirow[t]{2}{*}{5 year } & 0 & 0.6 & 0.66 & \multirow{2}{*}{0.26} & \multirow{2}{*}{1.944} \\
\hline & 0.868 & 0 & 0 & & \\
\hline \multirow[t]{2}{*}{10 year } & -0.002 & 0.349 & 0.518 & \multirow{2}{*}{0.155} & \multirow{2}{*}{1.911} \\
\hline & 0.424 & 0 & 0 & & \\
\hline \multirow[t]{2}{*}{20 year } & -0.007 & 0.114 & 0.319 & \multirow{2}{*}{0.026} & \multirow{2}{*}{1.955} \\
\hline & 0.15 & 0.07 & 0.04 & & \\
\hline \multirow[t]{2}{*}{30 year } & -0.007 & 0.138 & 0.334 & \multirow{2}{*}{0.041} & \multirow{2}{*}{1.969} \\
\hline & 0.15 & 0.07 & 0.05 & & \\
\hline
\end{tabular}

Notes: p-value from 399 bootstrap replications and Eicker and White Standard error, the estimates are expressed in percentage points

Table 9: The Response of British Interest Rates to BoE's and FED's surprise.

\begin{tabular}{|c|c|c|c|c|c|}
\hline \multicolumn{6}{|c|}{ The 1-day response of UK interest rates to BoE's and FED's surprise } \\
\hline & Intercept & $\begin{array}{c}\text { Response } \\
\text { BoE } \\
\text { Surprise }\end{array}$ & $\begin{array}{l}\text { Response } \\
\text { FED } \\
\text { Surprise }\end{array}$ & $\mathrm{R} \wedge 2$ & DW \\
\hline \multirow[t]{2}{*}{ Interbank 1 month } & -0.005 & 0.803 & 0.609 & \multirow{2}{*}{0.555} & \multirow{2}{*}{2.071} \\
\hline & 0.252 & 0 & 0.08 & & \\
\hline Interbank 12 month & 0.003 & 1.001 & 0.21 & \multirow{2}{*}{0.68} & \multirow{2}{*}{2.01} \\
\hline p-value & 0.343 & 0 & 0.171 & & \\
\hline \multirow[t]{2}{*}{2 year } & 0.001 & 0.699 & 0.351 & \multirow{2}{*}{0.41} & \multirow{2}{*}{2.039} \\
\hline & 0.808 & 0 & 0.11 & & \\
\hline \multirow[t]{2}{*}{5 year } & 0.004 & 0.459 & 0.225 & \multirow{2}{*}{0.191} & \multirow{2}{*}{2.12} \\
\hline & 0.404 & 0 & 0.212 & & \\
\hline 10 year & 0.005 & 0.277 & -0.109 & \multirow{2}{*}{0.05} & \multirow{2}{*}{1.916} \\
\hline p-value & 0.262 & 0 & 0.686 & & \\
\hline \multirow[t]{2}{*}{20 year } & 0.005 & 0.212 & -0.141 & \multirow{2}{*}{0.038} & \multirow{2}{*}{1.903} \\
\hline & 0.202 & 0.04 & 0.444 & & \\
\hline \multirow[t]{2}{*}{30 year } & 0.005 & 0.187 & -0.095 & \multirow{2}{*}{0.03} & \multirow{2}{*}{1.893} \\
\hline & 0.202 & 0.03 & 0.565 & & \\
\hline
\end{tabular}

Notes: p-value from 399 bootstrap replications and Eicker and White Standard error, the estimates are expressed in percentage points 